\title{
Miranda
}

Revue pluridisciplinaire du monde anglophone /

Multidisciplinary peer-reviewed journal on the English-

speaking world

23 | 2021

Modernist Exceptions

\section{Arts and Grafts: Marianne Moore's Poetry and the Culture of Exception}

\section{Aurore Clavier}

URL: https://journals.openedition.org/miranda/42440

DOI: 10.4000/miranda.42440

ISSN: 2108-6559

Publisher

Université Toulouse - Jean Jaurès

\section{Electronic reference}

Aurore Clavier, "Arts and Grafts: Marianne Moore's Poetry and the Culture of Exception", Miranda [Online], 23 | 2021, Online since 12 October 2021, connection on 29 November 2021. URL: http:// journals.openedition.org/miranda/42440 ; DOI: https://doi.org/10.4000/miranda.42440

This text was automatically generated on 29 November 2021.

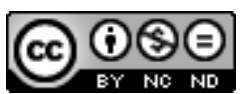

Miranda is licensed under a Creative Commons Attribution-NonCommercial-NoDerivatives 4.0 International License. 


\title{
Arts and Grafts: Marianne Moore's Poetry and the Culture of Exception
}

\author{
Aurore Clavier
}

\section{Fencing in/out: the space of poetry}

1 As readers of "Poetry" lured into finding a clear set of poetic principles rapidly discover, and as Moorean scholarship has amply shown, the editorial history of Moore's famous ars poetica is as convoluted as the argument it proposes to examine. From the original publication of the thirty-line syllabic poem in a 1919 issue of Others, to its spectacular reduction to a three-line epigram in the 1967 Complete Poems, until the recent restauration of the 1924 Observations version in the New Collected Poems, ${ }^{1}$ the changing forms and positions given to Moore's text within her unstable corpus have repeatedly put into relief the central tension that drives the text itself, pulled as it is between acceptance and exclusion:

Poetry

I too, dislike it: there are things that are important beyond all this fiddle.

Reading it, however, with a perfect contempt for it, one discovers that there is in

it after all, a place for the genuine. (Moore 27) ${ }^{2}$

2 If the generic title lays the ground for a common definitional enterprise, the speaker immediately takes, if not exception to, at least skeptical distance from the category it sets out to circumscribe, through a qualification that implicitly builds on Samuel Butler's own discarding of the genre: "I too, dislike it." Just as quickly however, a new turn of the verse readjusts the opening judgment, as the "contempt" with which "one" is invited to read poetry becomes the paradoxical condition for its critical reconsideration. The corrective play of the first lines only intensifies as the text unfolds its circuitous demonstration. In lieu of a stable limit clearly separating what poetry is from what it is not, the stanzas draw a most erratic line, alternatively accepting and excepting literary attitudes and materials alike, meandering between examples and exceptions, ${ }^{4}$ and gathering the author, the critic and the reader in a shared attempt to 
hone their discriminating abilities as much as the poet's own creative skills. Strikingly however, while the repeated provisos jeopardize the generic identity of the poem, the negative bent of Moore's ars poetica ironically leads the speaker to reject the principle of exclusion itself, when Tolstoy's tentative description of "poetry" as "everything with the exception of business documents and schoolbooks" 5 is eliminated in favor of an even more encompassing consideration of "all these phenomena" as equally valuable instances of the "genuine" and "raw" in poetry:

nor is it valid

to discriminate against "business documents and

school-books"; all these phenomena are important. One must make a distinction

however; when dragged into prominence by half poets, the result is not poetry,

nor till the poets among us can be

"literalists of

the imagination"-above

insolence and triviality and can present

for inspection, imaginary gardens with real toads in them, shall we have

it. (Moore 27)

3 Although the inclusive gesture is not meant to last-the revising rule of the poem suffering no exception-the text invites us to pause and consider, if only for a fleeting moment, the broad-gauge alternative it sketches out at this point. While rendering generic typology virtually impossible, the complex interplay between acceptance and exception veers to a seemingly more sweeping exploration of topology. If poetry cannot be defined and classified, Moore seems to suggest, at least the text may try to delineate a "place" it could either enfold or occupy, however conditionally or temporarily. As the "place for the genuine" we may "discover in it" ultimately ramifies into a multiplicity of "imaginary gardens with real toads in them," Moore operates the striking conversion of a literary topos into a hybrid poetic utopia, turning an apparently familiar "child's garden of verses" (Stevenson) into a cross locus, whose very existence is made to depend on its capacity to accommodate outlandish opposites.

4 Taking "Poetry" and its "gardens" as a point of departure rather than an ideal destination, I wish to investigate Moore's poetics of grafting as a case in point-or a special case?-in her paradoxical approach to representativeness and exception. The hybrid subjects she was particularly drawn to, like the literary transplants that characterize her quotational method of writing, seem to partake of a similar ideal of inclusion, potentially integrating isolated elements, unique specimens and even oddities within the bounds of a shared literary and political space. As we shall see, however, far from adhering to her country's dominant narratives of democratic exceptionality, Moore's crossings strikingly resist assimilation, the common rather allowing for her the encounter of unassimilable singularities.

\section{TEXTUAL TRANSPLANTS: THE ODD ONE IN?}

5 That Moore chose to remove her "imaginary gardens with real toads in them" from most revised versions of "Poetry" after 1925, ultimately appending the longer text as an endnote to her Complete Poems, certainly complicates the task of interpretation, but also reinforces the peculiar role played by the phrase in Moore's ambivalent culture of exception. While the marginalization of the full text as an appendix to a three-line 
poem-or in Hugh Kenner's terms as "a footnote to an excerpt from itself" (Kenner 1432-1433)-mimics the deferral advocated in its own conclusion, the critical success of its emblematic formula points in quite a different direction. Of all Moore's poetic coinages, "imaginary gardens with real toads in them" has certainly become the most famous, to the extent of being frequently transplanted into other texts and contexts. The formula's currency is not only attested by its diffusion among Moore scholars, and more largely specialists of Modernism, but is also evinced by its wider adoption in fields far removed from poetry. The phrase thus occasionally appears as a title or a subheading in specific studies of Moore's work (Frederick J. Hoffman's "Marianne Moore: Imaginary Gardens and Real Toads." or Charles Swann's "Gardens and Toads or, Milton-Another Fly in Marianne Moore's Amber?") or larger gatherings of twentiethcentury authors (Elizabeth Gregory's Quotation in Modern American Poetry: "Imaginary Gardens with Read Toads" or Rosemary Sprague's earlier Imaginary Gardens: A Study of Five American Poets). Just as often does it launch reflections about education, ethnography, religious ethics or psychotherapy. ${ }^{6}$ Isolated, transplanted, and not uncommonly distorted in order to fit their new textual environments, Moore's "toads" and "gardens" therefore reactivate, at the critical level, the apparently inclusive ethos they emblematize at the more local scale of the poem.

The seductions of Moore's trope certainly owe much to the poetic elasticity of its oxymoronic formula. If a garden is a toad's natural environment, its territory becomes virtually limitless, when made to receive specimens of the "real" within "imaginary" bounds. As Andrew Lakritz underlines, the confusion entailed by Moore's "complex chiasmus" is even more potent than it seems, as each of its elements may fall into opposite categories and contaminate its poetic surroundings in unexpected ways:

While gardens can be thought of as products of culture, fictional, constructed, and toads can be thought of as elements of the real, natural, given in the course of things by nature or God, on the other hand gardens can just as well be figured "With the thicket overgrown, grotesque and wild" as Milton puts it in Book IV (line 136) of Paradise Lost, while toads, as Barbary Babcock-Abrahams would have it, present a creature that in its doubleness refuses to assimilate itself to our notions of the real, the natural. (Lakritz 129)

7 More broadly, the various crossings Moore operates within the microcosm of a single phrase ramify through the entire poem, there too revealing the coexistence of seemingly unassimilable planes. A possible variation on the animal behaviors listed in the previous stanzas, as models for a more instinctive approach to poetry, the gardens and toads could simply indicate a thematic interest for natural subject matters. As a metaphor, the conceit more broadly tropes the integration of disparate notions into the common perimeter of the text, reality and imagination thus resonating with other pairs of more or less explicitly voiced opposites-nature and artifice, poetry and prose, criticism and creative writing, high and low, to name a few. In turn, the phrase also becomes the token of Moore's own compositional method, as it signals the material insertion of fragments taken from other sources into the fabric of the poem.

As reminded by Elizabeth Gregory, in her study of quotation and American modernist poetry, the roots of quotational writing run deep into literary history, but the practice took unprecedented shapes and significance in the hands of modernist authors: the proliferation of quotations in such works as Pound's, Eliot's, Williams', Joyce's or Zukofsky's did not only draw attention to the material specificities of their literary medium, in ways comparable to collage art in the visual field, but it also came to 
epitomize the "paradoxical historical situation" of a generation whose claims to originality was intrinsically tied to their anxious awareness of the past (Gregory 1996, 3). Although Moore's technique shares similar features and concerns, it also stands as a rather special case, both in the degree to which it manifests itself in her writing and in the ambiguity of its interactions with the original text. While, Gregory observes, the proportion of quoted phrases increases significantly throughout Moore's career, ${ }^{7}$ the complexity of her method is rendered more visible by her wide-ranging selection of materials, some borrowed from consecrated authors (Biblical prophets, Spenser, Shakespeare, Milton, or Trollope to name a few), but most of them extracted from less "exceptional" sources such as minor works, low-brow publications or non-literary items. And if Moore seemingly abides by the rules of literary tribute when explicitly pricing "relentless accuracy" (Moore 77), using quotation marks or referencing her sources in her poems or endnotes, more often than not, the traces of her manipulations are partly, if not entirely, erased, as Moore scholars accustomed to her treasure hunts know too well. "Imaginary gardens with real toads in them" is no exception to the rule: while in the longer version reproduced in Moore's endnotes to the Complete Poems, the phrase is framed by quotation marks, therefore clearly marking the words as borrowed, the punctuation is actually absent from earlier editions of the text (including the one quoted above). ${ }^{8}$ In such cases, readers can only intuit the foreign provenance of the fragment: they might then identify a potential echo to previously quoted excerpts ("business documents and school-books," borrowed from Tolstoy, and "literalists of the imagination," a distorted version of Yeats' qualification of Blake as "a too realist of the imagination" mentioned in Moore's endnotes ${ }^{9}$ ), but they might also sense the fainter redolences from Williams' "Romance Moderne" ${ }^{10}$ and Milton's Paradise Lost, ${ }^{11}$ or recognize a hybridized version of such fairy tales as "The Frog Prince", "Cinderella" or "Rapunzel" for example.

9 Operating simultaneously at the level of the phrase, the text, its literary transmission and its critical reception, the transplant therefore evinces the various transformations at work in the act of grafting, from the extraction of a singled out fragment to its inclusion into a new organism and its potential assimilation. In Moore's hands, the apparently loose prepositions that adorn imaginary places "with" real creatures, and place toads "in" their respective gardens, ultimately give shape to one of the "heuristic metaphors" underlying the process of quotation according to Antoine Compagnon:

Quotation is a foreign body within my text, because it does not properly belong to me, because I appropriate it. Its assimilation, like an organ transplant, thus involves the risk of a rejection against which I need to forearm myself, and which I jubilate to avoid. The transplant holds, the operation succeeds: I know the satisfaction felt by the conscientious craftsman when he yields a finished product bearing no trace of his labor, his empirical interventions. Such is also, to a greater degree, the surgeon's enjoyment when he inscribes his knowledge and his skill onto the patient's body: the surgeon's talent is measured by the neatness of his work, the fairness of the scar with which he signs and authenticates his work. The quotation is plastic surgery, where I am simultaneously the aesthete, the surgeon and the patient: I pin some chosen parts which will become ornaments, in the strong sense that ancient rhetoric and architecture give to the word, I graft them to the body of my text (like Proust's paper strips). The tacking must disappear under the finish, and the scar itself (the quotation marks) will be an additional embellishment. (Compagnon 32-33; translation mine)

10 If Moore's writing method bears resemblance to the surgeon's operation, she seems to have been more sensitive to its botanical counterpart, as many other poems suggest, in 
addition to "Poetry." ${ }^{12}$ Her education and readings partly explain her preference. While a student at Bryn Mawr in the early $20^{\text {th }}$ century, Moore cultivated her taste for science by taking extensive courses in various branches of biology. ${ }^{13}$ Interestingly, she made better grades working in the laboratory than in writing classes, where she was reproached with her digressive tendencies and her sprawling "network of quotations" (Leavell 2013, 67). Although she finally majored in "History and Economics and Politics" and, after various positions as a teacher or a librarian, soon embraced a literary career, she kept a life-long fascination for natural sciences. Drawing from her personal library, notebooks, and collections of paper clippings, Robin Schulze gives a useful sample of her scientific interests:

She studied John J. Audubon's birds, Jean Henri Fabre's insects, Ronald Lyddeker's mammals, and Alphonse De Candolle's plants. She read works by the popular nature writers John Burroughs, Raymond L. Ditmars, W. H. Hudson, and Ernest Thompson Seton, and copied passages from the books of conservationist John Muir. She clipped pictures from National Geographic Magazine and Natural History and scrupulously studied articles written by naturalists J. Arthur Thomson and W. P. Pycraft that appeared in the science pages of the Illustrated London News. She read pieces about the instruction and social application of evolutionary biology by Henry Fairfield Osborn, J. B. S. Haldane, Edward Murray East, Leonard Darwin, and Havelock Ellis. She frequently graced the halls of the American Museum of Natural History and the grounds of the Bronx, Prospect Park, and Central Park zoos. (Schulze 1998a, 5)

As Schulze also notes, Moore was especially intrigued by the reciprocal influences between natural and cultivated plants through various techniques of grafting, acclimation and cultivation, as suggested by the abundant notes she took from Darwin's 1868 study of The Variation of Animals and Plants Under Domestication, and Alphonse De Candolle's The Origin of Cultivated Plants (1895) (Schulze 1998a, 9, and passim). These works and topics naturally found their way into her own writing. Next to her notorious "animiles," as she once named such animal poems as "The Jerboa", "The Plumet Basilisk", "The Frigate Pelican", "The Buffalo", or "Pigeons"14, Moore's collections also include pieces with a more specific focus on botanical items. Most of them bear the traces of natural or artificial crossings which, as in "Poetry", the poems themselves replicate in their lavish use of quotation. First published in 1925, "The Monkey Puzzler"15 thus attempts to retrace the complex ramifications that characterize both the appearance and the origins of the Chili Pine (also known as the monkey puzzle or araucaria auraucana), “an interwoven somewhat"' (Moore 26), whose intricacies seems to owe as much to the animal reign as to the vegetable one. Written almost a decade later, "Camellia Sabina" links the carefully elaborated cultures of various French delicacies-hothouse flowers, plums, vine, and wine-before concluding with a striking blend of languages:

The gleaning is more than the vintage, though the

history de la vigne et $d u$ vin place a

mirabelle in the bibliothèque

unique depuis seventeen-ninety seven. (Close

the window, says the Abbé Berlèse,

for Sabina born under glass.)

(Moore 106)

In similar fashion, "Nine Nectarines and Other Porcelains" celebrates the appropriateness of Chinese arts and wisdom, through a comparison between the 
respective merits of European and Asian porcelains, which takes its roots in her botanical observations on painted and natural-but always hybrid-fruits:

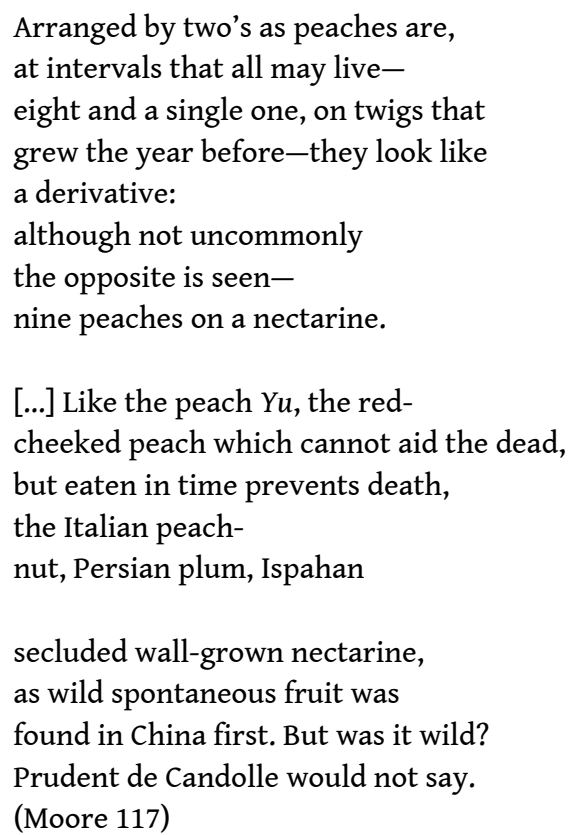

13 Another transplant appears later in Moore's career with "The Camperdown Elm"-"Gift of Mr. A. G. Burgess to Prospect Park, Brooklyn, 1872", the epigraph says-in whose defense Moore resuscitates Thomas Cole and William Cullen Bryant's "Kindred Spirits" as painted by Asher Brown Durand, attaching the evocation of their artistic correspondence to her own celebration of the imported Brooklyn tree and "the intricate pattern of its branches" (Moore 265).

\section{"IN THE PUBLIC gARDEN": AN AMERICAN COMMON?}

If Moore's meticulously crafted stanzas evidently display her "capacity for fact" (Moore 77) and the mere pleasure taken in attentive description, their grafted specimens and the poetical crossings they inspire are more deeply rooted in political ground than they appear to be. Although the few titles mentioned above seem to limit our gaze to a close focus on plants, the lines they introduce rapidly open up the scope to a larger consideration of their natural or artificial surroundings and the various interactions they entail, making it impossible, for instance, to isolate "The Camperdown Elm" from the urban park it stands in, or to separate the cultures of the "Camellia Sabina" and "Nine Nectarines" from the civilizations they epitomize. More poems would fit into this extended view, bearing titles which do not so much designate a specific subject as the environment shared by multiple specimens ("Virginia Britannia" or "In the Public Garden" for example), or more indirectly lead us from animal or human descriptions to a careful exploration of the surrounding flora ("The Fish" or "The Steeple Jack" giving way to a larger consideration of their coastal ecosystems for instance).

As Robin Schulze argues, against the frequent critical view of Moore's plant and animal poems as strategic guises concealing or subduing more personal anxieties, Moore's natural subjects fully invest the spaces unfolded by her texts, if only as a sign of defiance, thus publicizing, however circuitously, the poet's participation in the political 
debates of her time (Schulze 1998a, 3-4; 2005, 74-76). The possible responses to alterity, foreignness, or oddity were of particular interest to Moore, whose verse relentlessly addresses questions of cultural appropriation, national assimilation, or social inclusion. As has been often noted, a large proportion of her poems display an early and enduring commitment to environmental reflections, by resisting the various forms of physical or mental appropriation imposed upon nature by human civilizations, or blending natural processes and cultural representations in order to contest the primacy of man's falsely transparent gaze. ${ }^{16}$ Mount Rainier for example is represented as a National Park, a neatly circumscribed portion of the wilderness, but also as a glacier, "An Octopus / of ice" (its title and first line), whose stealthy growth escapes our pretensions to knowledge, and whose ability to integrate diversity and ingest differences paradoxically prevents any form of possession.

An Octopus

of ice. Deceptively reserved and flat, it lies "in grandeur and in mass"

beneath a sea of shifting snow-dunes;

dots of cyclamen-red and maroon on its clearly defined pseudopodia

made of glass that will bend-a much needed invention-

comprising twenty-eight ice-fields from fifty to five hundred feet thick,

of unimagined delicacy.

"Picking periwinkles from the cracks"

or killing prey with the concentric crushing rigor of the python,

it hovers forward "spider fashion

on its arms" misleadingly like lace;

its ghostly pallor changing

to the green metallic tinge of anemone-starred pool."

[...] Completing a circle,

you have been deceived into thinking you have progressed.

(Moore 72)

Other poems propose to address more strictly social questions through the biological prism. For instance, "Roses Only", "Radical" or "Injudicious Gardening" have been read as various expressions of Moore's challenge to the gender stereotypes inherited from the $19^{\text {th }}$ century. ${ }^{17}$ The poet's stand against the racism at work in nativist and eugenic ideologies, immigration policies or segregationist oppression finds adequate terrain in the moralized landscapes of "Spenser's Ireland", "Nine Nectarines and Other Porcelain" or "Virginia Britannia."18 And while "England" proposes a new cartography of cultural values, by shifting its perspective from the refined sceneries of the Old World to the raw territory of "America", "Virginia Britannia" turns against the dominant colonial narratives of the same continent by pointing out the original violence underlying the lush vegetation and delicate flower-beds of the "Old Dominion" and the former colony of Jamestown, its sinuous design and hidden quotations uncovering the resilience of native vegetation or of the "jet black pansies" and "African violet"

Narrow herring-bonelaid bricks,

a dusty pink beside the dwarf-box

bordered pansies, share the ivy-arbor shade

with cemetery

lace settees, one at each side,

and with the bird: box-bordered tide-

water gigantic

jet black pansies (splendor; pride;) 
not for a decade

dressed, but for a day, in

overpowering velvet; and

gray blue-Andalusian

cock-feather pale ones

ink-lined on the edge, fur-eyed, with ochre

on the cheek. The slowmoving glossy, tall

quick cavalcade

of buckeye-brown surprising

jumpers, the contrasting work-mule and

show-mule \& witch-cross \& "strong sweet prison"

are part of what

has come about, in the Black

idiom, from advancing back-

ward in a circle;

from taking The Potomac

cowbirdlike; and on

The Chickahominy

establishing the Negro, opportunely brought, to strength-

en protest against

tyranny. Rare unscent-

ed, provident-

ly hot, too sweet, inconsistent flowerbed!

old Dominion

earth makes sunflower-heads grow large:

hibiscus and so-called mimosa

close at night; the scarlet peculiarly-quilled

pomegranate-petals,

the African violet,

and camellia, perfumeless. Yet

house-high glistening green

magnolia-trees with velvet-

textured flower, are filled

with anaesthetic scent

enough to make one die; (Moore 132-133)

If this brief panorama of Moore's political landscapes spans her entire career, various critics have noted the growing explicitness of her engagement with the public arena after the 1930s. In her introduction to the facsimile edition of poems published between 1936 and 1941, Heather Cass White recapitulates the political, artistic and personal events that led Moore to develop a more straight-forward mode of expression (White, in Moore 2012, xi-xiii). The degradation of international relations until their final shattering after 1939, the politicization of the literary scene which some felt was incompatible with the elitism of more experimental ventures, and the death a beloved mother, with whom Moore had shared her whole life and career, collectively account for the inflections of her style, an evolution which may also stem from more enduring accusations of obscurity, as Robin Schulze posits in her analysis of the poet's textual "Darwinism" (Schulze 1998b). And indeed, if the specimens Moore observes in her poems of the 1910s and 1920s involve more than mere scientific or aesthetic appreciation, the natural and literary spaces they occupy are hardly ever as open as in her later production. When the anonymous speaker of "Injudicious Gardening" 
condemns the conventional symbolism of flowers, by stepping into the private sphere of Robert Browning's garden and correspondence with Elizabeth Barrett, at the other end of the spectrum, "In the Public Garden," provides the more clearly autobiographical testimony of a poet invited to read at a public festival, and inspired to reflect on the historical significance of Boston and its common:20

In the Public Garden

Boston has a festival-

compositely for all-

and nearby, cupolas of learning

(crimson, blue, and gold) that

have made education individual.

My first-an exceptional,

an almost scriptural-

taxi-driver to Cambridge from Back Bay

said, as we went along, "They

make some fine young men at Harvard." I recall

the summer when Faneuil Hall

had its weathervane with gold ball

and grasshopper, gilded again by

a -leafer and -jack

till it glittered. Spring can be a miracle

there-a more than usual

bouquet of what is vernal-

"pear blossoms whiter than the clouds," pin-

oak leaves that barely show

when other trees are making shade, besides small

fairy iris suitable

for Dulcinea del

Toboso; O yes, and snowdrops

in the snow, that smell like

violets. Despite secular bustle,

let me enter King's Chapel

to hear them sing: "My work be praise while

others go and come. No more a stranger

or a guest but like a child

at home." A chapel or a festival

means giving what is mutual,

even if irrational:

black sturgeon-eggs-a camel

from Hamadan, Iran;

a jewel, or, what is more unusual,

silence-after a word-waterfall of the banal-

as unattainable

as freedom. And what is freedom for?

For "self-discipline", as our

hardest-working citizen has said-a school (Moore 219-220) 

collecting flowers and quotations alike, assembling them in a "more than usual bouquet of what is vernal", announcing the other gifts which circulate within the enclosure of the park and the symbolic setting of the festival-exotic objects but also a poem to be read publicly. The particolored display of flowers appearing side by side, in more or less conspicuous fashion, offers a miniature replica of Moore's stroll between present and past sites, from Back Bay to Cambridge, or among the familiar landmarks of Puritan and Republican history-King's Chapel, Faneuil Hall, Harvard, or the freedom trail. The civic values of liberty, instruction or self-discipline these sites emblematize are both examined and shared anew through the various excerpts Moore collects from the Scriptures, a religious hymn, a historical record or an occasional conversation.

In this context, it may be tempting to view the public garden not only as a figuration of the public arena, but also as an open celebration of democratic inclusion. The horticultural cohesion of the common, like the "bouquet" of excerpts collected and mingled in the text, would then require of the poet not to stand out as an exception, but to represent a collective model of citizenship, integrating the diverse and acclimatizing the foreign into a single literary organism. Remarking on the dual influence of evolutionary theory and political thinking in her college education David Ross Anderson, for example, observes that: "[b]y comparing biological and political systems in her poetry, Moore uses nature as a symbol of, and model for, the organic community to which republics should aspire". In an attempt "to reconcile Darwinian biology with religious faith, and accordingly to preserve eighteenth-century conceptions of natural law as the basis for American political institutions", Ross argues, Moore insists that the poet fully contribute to the cohesion of the republican community, more especially in times of social, economic or political adversity (Anderson 31, 33, and passim).

As has been often noted, and sometimes deplored, Moore's late poetic inflections precisely coincided with her growing role as a celebrity. After the Second World War, and especially following her triple literary crowning-in 1953, she was awarded the prestigious Pulitzer Prize, Bollingen Prize and National Book Award for her Collected Poems-, recognition extended well beyond the avant-garde circles that had admired her demanding work since the 1910s. In addition to participating in public readings, answering innumerable letters, or advising aspiring authors, her new fame also involved posing in middle-brow magazines, pitching the first ball at the season opening baseball game, inventing car names for the new Ford model, or featuring in an airline commercial for example. Moore's active citizenship was not only perceptible in her increasingly occasional poetry, through pieces dedicated to public figures, cultural events or political debates, but also emblematized by the cape and tricorn hat which, after 1953, became her most recognizable visual signature, an artist's uniform David Ross Anderson associates to a "republican tradition embodying beliefs in civic virtue, vigilance against tyranny, pluralism, and self-restraint" (Anderson 31).

\section{One of a kind: singular crossings}

Such was not, however, Moore's effect on her contemporaries, nor was her poetry exactly received as a representative form of expression. As Anderson specifies many rather "speculated that the tricorn was a mere affectation of fashion or, worse yet, an 
eccentric parody of George Washington" (Anderson 31). In accordance with this other picture, literary evocations of the poet's character and surroundings often conjure up related images to define the oddity of her looks, manners or expression. For those who tried to situate her within a specific tradition, she seemed to elude any clear temporal and geographical definition, since she could simultaneously embody contemporary America, baroque or classical France, or early modern England for instance. ${ }^{21}$ More gendered portraits alternatively cast her as "a sort of Mary Poppins of poetry" (Ashbery quoted in Gregory 2003, 223), "someone's fairy godmother incognito" (Plath 168), living in a "bower-bird bric-a-brac" in Brooklyn (Hughes 1998, 75), a respectable magician invited by Elizabeth Bishop to come "flying" over to a morally approvable version of Manhattan (Bishop 82-83). "Miss Moore" then was to her late contemporaries less of a representative citizen than a curious exception, just as she had represented, to her early (mainly male) peers, an oddly chaste or hysterical virgin, the saint of a literary worship, or a modern version of the recluse poet. ${ }^{22}$ Whatever the period they typify or the agenda they reveal, such evocations evidently betray larger historical assumptions about women's long marginal place on the literary scene. Several critics have indeed noted the obvious prejudice underlying these portraits of Moore the modest maid or the fanciful spinster, and the equation they involve between the author's singularity and her singleness, whether in order to celebrate her unique achievement or to downplay her literary production and her late poems in particular. ${ }^{23}$

Reductive as they might seem, these accounts nonetheless carry a paradoxical truth, which goes beyond mere biographical fact. Certainly, Moore never married, nor is she known to have been involved in any kind of sentimental relationship. But more importantly, both her verse and prose suggest that celibacy was to her not only a matter of life choice, but a literary value as well. As Linda Leavell notes in an article dedicated to "Marianne Moore, the James Family, and the Politics of Celibacy", a great number of her intellectual models were "blameless bachelors", a term she borrowed from Henry James, a favorite author in her personal pantheon. Surfacing in several essays or in poems like "An Octopus" or "The Frigate Pelican", James then, but also Handel, Newton or Beethoven enabled her to assert her own resistance to the "Freudian necessity" of marriage and to the alternative model of same-sex companionship, not only evading the most traditional notions of sexual politics, but also more feminist grids of interpretation (Leavell 2003, 223, 235, 239). Evoking "Marriage", Moore's "modernist epithalamium", and the strategies the poem employs to challenge "this institution / perhaps one should say enterprise / [...] requiring all one's criminal ingenuity / to avoid" (Moore 63), Sandra Gilbert summarizes the perplexing effect provoked by the author's neutralization of sex and gender:

Indeed, it is more specifically through its noncommittal alienation than through its committed feminism that this extraordinary text reveals the direction in which Moore's pose as "spinster schoolteacher" would take her.

To be even more specific: "Marriage" is obviously spoken by someone to whom what Adrienne Rich has called "compulsory heterosexuality" has simply never seemed either "compulsory" or compelling. Not that it is what Rich might call a "lesbian" poem; it is simply a soliloquy that stands entirely outside sexuality to look at its conventions from, as it were, an extraplanetary perspective-or, perhaps more accurately, from the point of view of an entirely self-sufficient, apparently asexual creature, a genius of an amoeba, say. (Gilbert 35)

It is tempting to recognize in this (in)definition of Moore's autonomous and neutral persona an echo of the peculiar specimens that regularly feature in her verse. Even 
when their denomination and description seem to make them the representatives of a particular family, genus or species, and to partake of a larger system of classification based on the identification of common features, the animals or plants her verse centers on generally appear alone, in the singular form, whether as the main focus of a whole text ("The Sycamore," "The Plumet Basilisk," "The Arctic Ox (or Goat)," "The Pangolin"), ${ }^{24}$ or at the more local scale of its stanzas," as shown in "Virginia Britannia." The effect is even more blatant when Moore manifests her taste for strange real or imaginary cases which resist all forms of categorization. The Renaissance taste for curiosities like the scientific enigmas of evolution equally inspire Moore's predilection for natural oddities. While the unicorn, the plumet basilisk, the pangolin or the paper nautilus are singled out as rarities or felicitous anomalies in the animal reign, the Camperdown Elm or the monkey puzzle, despite their association to a specific habitat, seem impossible to assimilate with other trees. If the defense of the Camperdown Elm becomes a common cause for New-Yorkers ${ }^{25}$ in support of which the poet resuscitates a shared cultural patrimony embodied by Thomas Cole, Asher B. Durand and William C. Bryant, as we have seen, the tree is also celebrated as a superlative exception, whose seductions surpass the respective beauties of Europe and America Bryant compares in his "Sonnet to an American Painter Departing for Europe":

No doubt they had seen other trees-lindens;

maples and sycamores, oaks and the Paris

street-tree, the horse chestnut; but imagine

their rapture had they come on the Camperdown elm's

massiveness and "the intricate pattern of its branches,"

arching high, curving low, in its mist of fine twigs.

[...]

Props are needed and tree-food. It is still leafing;

still there; mortal though. We must save it. It is

our crowning curio. (Moore 265)

Thus visually set apart from the left margin, "our crowning curio" stands out as a priceless, but also vulnerable exception. By detailing the specific treatment needed by the tree, the concluding lines implicitly remind us that it is a fragile rarity, one of the few existing specimens produced by a grafting operation, to suit the Victorian taste for gardenesque curiosities, and therefore unable to reproduce itself through a natural process. A comparable strangeness characterizes "The Monkey Puzzler": although it does not stem from any human intervention and, Moore's notes indicate, ${ }^{26}$ is here again presented in its original Chilian environment, the Chili pine or araucaria araucana imbricata does not only puzzle the monkey but also the evolutionist who, in the wake of Darwin, is at pains to retrace its genealogical tree and understand "why it should be here":

The Monkey Puzzler

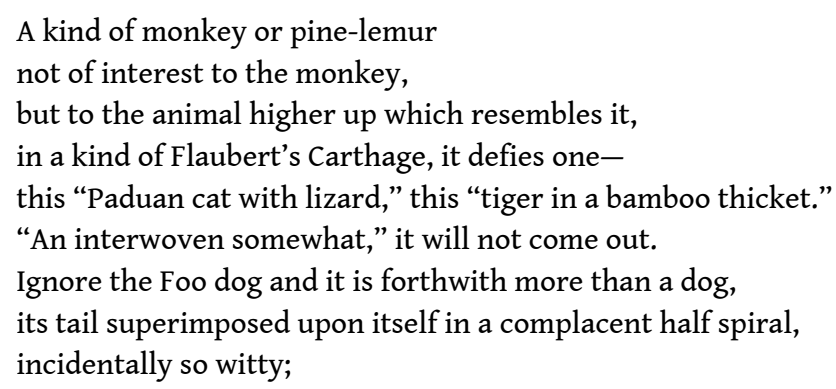


but this pine-tree-this pine-tiger, is a tiger, not a dog.

It knows that if a nomad may have dignity,

Gibraltar has had more-

that "it is better to be lonely than unhappy."

A conifer contrived in imitation of the glyptic work of jade and hard stone cutters,

a true curio in this bypath of curio collecting,

it is worth its weight in gold but no one takes it

from these woods in which society's not knowing is colossal,

the lion's ferocious chrysanthemum head seeming kind in comparison.

This porcupine-quilled, infinitely complicated starkness-

this is beauty-"a certain proportion in the skeleton which gives the best results."

One is at a loss, however, to know why it should be here,

in this morose part of the earth-

to account for its origin at all;

but we prove, we do not explain our birth. (Moore 26)

The "puzzle" of the title becomes increasingly intricate as the monkey or the lemurtheir elongated arms recalling the spiny branches of the tree which nonetheless prevent them from climbing up-give way to more convoluted ramifications. The pine thus alternately or simultaneously conjures up disparate specimens (the tiger, the dog, the lion or the porcupine), or introduces new crossings between the vegetable, the animal and the mineral worlds ("the lion's ferocious chrysanthemum head"; "A conifer contrived in imitation of the glyptic work of jade and hard stone cutters" and endowed with a "skeleton"). The deeper this Darwinian exploration of origins takes the reader, the more unsolvable its evolutionary puzzle becomes, as it unfolds its series of paradoxes, making apparent resemblances turn into unrelatable oddities. If the unexpected results of hybridization may therefore recall the fertile process of "creolization" Edouard Glissant describes as the unforeseeable product of the encounter, imbrication and confusion between "cultural elements come from radically diverse horizons" (Glissant 15; translation mine), the poem actually shares none of the proliferating tendencies he attaches to his fertile "poetics of relation." The more composite the specimen appears, the more unique, insulated and unrelatable it becomes. In addition to being endemic to some remote "woods in which society's not knowing is colossal", a "morose part of the earth" whose isolation partly inspired Darwin's theory, the Chili pine is itself set apart, "a true curio in this bypath of curio collecting," aware that "it is better to be lonely than unhappy". Though this "interwoven somewhat", this "kind of monkey [...] in a kind of Flaubert's Carthage [...] will not come out", it certainly stands out as a "Gibraltar" rock, an obstinate "this", an exception whose presence is impossible to explain, but also to ignore.

Moore's horticultural curiosities therefore call for a more fine-grained description of her poetics of grafting. Rather than fuse its heterogenous elements into a new whole, the associative process of "The Monkey Puzzler" only seems to juxtapose them in a series of temporary combinations, without threatening the integrity of each. What the prepositions and the hyphens appear to attach, the negations immediately separate, before a new composition is tested. This resistance to assimilation contaminates the quotations, which the text refuses to fully absorb, revealing their foreign origin instead. All of Moore's borrowed fragments, except one,$^{27}$ are clearly marked off, but unreferenced, a "collection of flies in amber" (Moore 1981, 551), we can see, but whose origin, like that of the tree, cannot quite be traced. Far from becoming part of a new organism, the excerpts are circumscribed to appositions, autonomous semantic 
surpluses, which do not quite fit into the organic body of the sentence, as the dashes underline, simultaneously operating as stitches and incisions between ideas.

This riddling effect is by no means limited to a few isolated cases. If single specimens often feature as the sole focus of numerous poems, they can also cross paths with others in ways that also question the process of assimilation on which the successful transplant rests. If the exploration of the historical and natural microcosm of "Virginia Britannia", as we have seen, sketches out a public arena, from which the speaker may interrogate the foundations of the national community, the picturesque harmony between human ruins and local vegetation progressively gives way to a more "inconsistent flowerbed" (Moore 233), a luscious array of individual plants bearing the stigmas of violent transplants and predatory interactions. Although the poem ultimately returns to a more integrative picture, as several individual specimens become "one tree" against the blazing sunset (Moore 135-136), assimilation appears irreversibly compromised by the cracks of American history. In a lighter perspective than "Virginia Britannia," with which it originally featured in the "Old Dominion" grouping, "Smooth Gnarled Crape Myrtle" is also built on a series of peculiar crossings. For while crossings do occur here, they rather evoke a geographical or geometrical series of intersections:

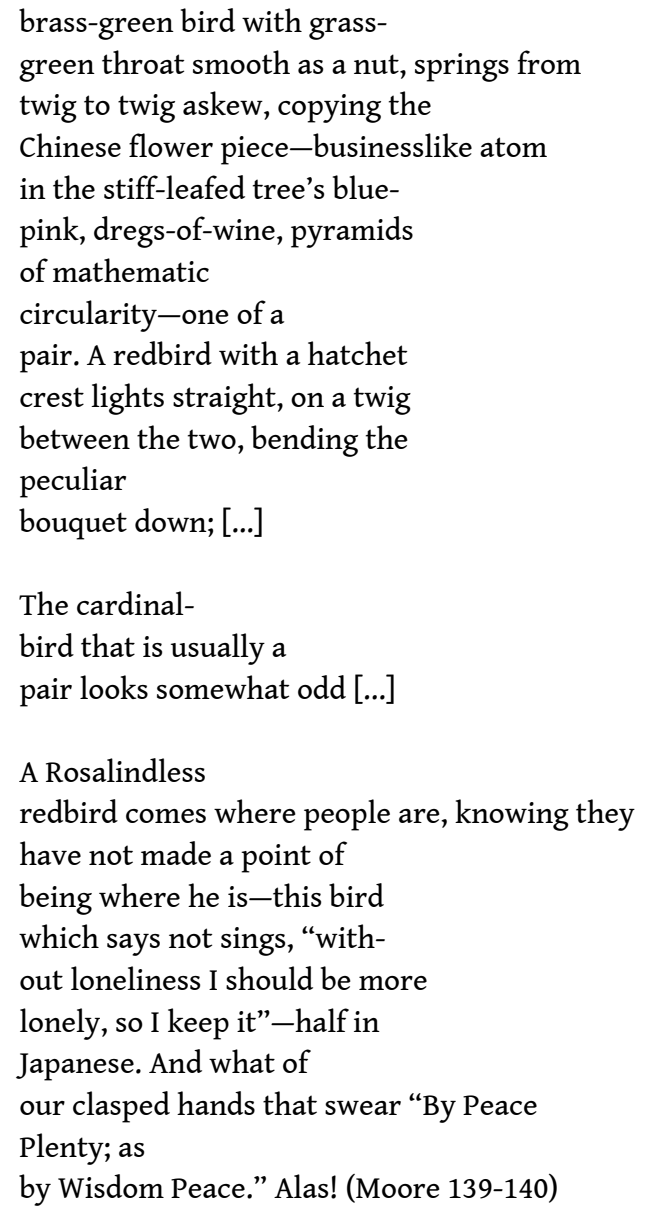

The ramifications of the tree form a tight but neat grid, where forms move about, but never quite mingle. Specks of colors, moving atoms, dots, lines and mathematical planes distinctly stand out through the cutting edges of the stanzas. The numerous monosyllables and their hard consonant clusters mimic the hopping movements of the birds but also prevent any phonetic assimilation between words, while the poem also 
displays the radical cuts Moore notoriously imposed upon compound words or grammatical units, therefore splitting whatever link might appear through movements, shades, resemblances. Although the birds mentioned are supposed to form pairs, intruders or prosodic ironies continuously isolate them. The "Smooth-Gnarled Crape Myrtle" therefore becomes the divided habitat of split pairs and odd specimens, whose jerky ballet compromises the adaptation of the sentimental tradition the bird has come to symbolize. Quotations, mottoes, or intertextual allusions do not form a web as much as an odd grid, where mating gives way to more disjunctive encounters. Just as creatures keep crossing each other's path, ancient or contemporary, foreign, or local, stately or vernacular literatures and languages circulate and meet, but avoid synthesis. Half-heard, italicized, such imports remain foreign to the poem they inhabit as Moore's singular "bird's claw" playfully tips the scales of love poetry in favor of loneliness and peculiarity. (Untranslated) Japanese, Persian songs, Sanskrit vestiges, but also troubadour canzos, Shakespearean comedy, romantic odes, and modernist rewritings are simultaneously gathered and isolated, or like the hands of the final emblem, "joined/in friendship", but split by the verse. The solitary unions Moore fosters therefore conjure up the enlightening distinction made by Jean-Luc Nancy between the melee (mêlée) and the melange (mélange) in an essay written at the time of the Yugoslavian partition:

The melange then is not. It happens, it occurs. A melee, crossing, weaving, exchange, sharing arises, and it is never one, nor the same thing. On the one hand, the melange is an "it happens", not an "it is"; displacements, happenstances, migrations, clinamens, encounters, blessings and risks. On the other hand, it is not one: a melee implies encountering and countering, gatherings and divergences, contacts and contracts, what concentrates and what disseminates, what identifies and what alters. (Nancy 12; translation mine)

Far from being limited to the specific context of the 1930s, the radical singularity evinced in "Virginia Britannia" and "Smooth Gnarled Crape Myrtle" partake of a more sweeping resistance to historical or literary assimilation. Despite the inclusive gesture of its democratic address, "In the Public Garden" finally shares much of the critical insulation at work in Moore's botanical cases. As the poet's 1958 stroll draws to a close, the poem appears to fold upon itself when seemingly at its most open. Taking over from the multiple dialogues she stages in her verse, the speaker seizes the opportunity of a virtual question ("And I?") to regraft her own voice to her fellow-citizens':

And I? This is no madrigal-

no medieval gradual-

but it is a grateful tale.

Without that radiance which poets

are supposed to have-

unofficial, unprofessional, still one need not fail

to wish poetry well

where intellect is habitual-

glad that the Muses have a home and swans-

that legend can be factual;

happy that Art, admired in general,

is always actually personal. (Moore 220)

Under the apparent effacement of a humbly occasional piece she feigns not to call a poem, the speaker's voice becomes strikingly audible, making Moore's idiosyncratic 
language clearly stand out of the common idiom of the United States, that "plain American that cats and dogs can read" (Moore 49). Speech may very well circulate and appear as unexceptional as the unaccented [əl] rhyme that dominates her poem, but within the common space of the "habitual", the "factual" or the "general", Art persists in being always "actually personal".

As "In the Public Garden" discreetly reaffirms, it takes various individuals to share a mutual space. However inclusive, Moore's common remains an odd garden, a collection of rarities, a sample of exceptions. As the poet's horticultural "bachelors" show, grafting is not mingling. Singled out, imported, clamped, acclimated, the scions may firmly hold to their respective stocks but rarely lose their power of estrangement: a botanic or poetic hybrid, with Moore, remains an isolated case, a "creative composite" (Kroiz 2012) whose result is impossible to deduce but also to reproduce. Unless a new transplant should add up to the first, introduce a new peculiar specimen, open up ever new "space[s] for the genuine". Poetry is not one, but several, an exception spawning exceptions, a mutually shared but necessarily plural collection of "imaginary gardens with real toads in them".

\section{BIBLIOGRAPHY}

Anderson, David R. "The Woman in the Tricorn Hat: Political Theory and Biological Portraiture in Marianne Moore's Poetry.” Journal of Modern Literature 22:1 (Autumn 1998): 31-45.

Ashbery, John. "Straight Lines over Rough Terrain." The New York Times Book Review (26 Nov. 1967): 1, 42. In The Critical Response to Marianne Moore. Ed. Elizabeth Gregory. Westport: Praeger, 2003. 222-226.

Bishop, Elizabeth. The Complete Poems, 1927-1979. New York: Farrar, Straus \& Giroux, 1983.

Booth, David. “'Imaginary Gardens with Real Toads': Reading and Drama in Education.” Theory Into Practice 24:3 (1985): 193-198.

Compagnon, Antoine. La Seconde Main, ou le Travail de la Citation. Paris: Editions du Seuil, 1979.

Costello, Bonnie. Marianne Moore: Imaginary Possessions. Cambridge: Harvard University Press, 1981.

---. Shifting Ground: Reinventing Landscape in Modern American Poetry. Cambridge: Harvard University Press, 2003.

Gilbert, Sandra. "Marianne Moore as Female Impersonator." In Marianne Moore: The Art of a Modernist. Ed. Joseph Parisi. Ann Arbor: UMI, 1990. 26-46.

Glissant, Edouard. Introduction à une Poétique du Divers. Paris: Gallimard, 1995.

Gregory, Elizabeth. The Critical Response to Marianne Moore. Westport: Praeger, 2003.

---. Quotation and Modern American Poetry: “Imaginary Gardens With Real Toads." Houston: Rice University Press, 1996. 
---. “Stamps, Money, Pop Culture and Marianne Moore." In The Critical Response to Marianne Moore. Ed. Elizabeth Gregory. Westport: Praeger, 2003. 234-246.

---. “'Still Leafing': Celebrity, Confession, Marianne Moore's ‘The Camperdown Elm' and the Scandal of Age." Journal of Modern Literature 35:3 (2012): 51-76.

Hecht, Anthony. “Writer's Rights and Reader's Rights.” Hudson Review 21 (1968): 208-209.

Hoffman, Frederick J. “Marianne Moore: Imaginary Gardens and Real Toads.” Poetry 83:3 (Dec. 1953): 152-157.

Holley, Margaret. The Poetry of Marianne Moore: A Study in Voice and Value. Cambridge: Cambridge University Press, 1987.

Honigsblum, Bonnie. “Marianne Moore's Revisions of 'Poetry." In Marianne Moore: Woman and Poet. Ed. Patricia Willis. Orono: National Poetry Foundation, 1990. 185-222.

Hughes, Evan. Literary Brooklyn: The Writers of Brooklyn and the Story of American City Life. New York: Henry Holt and Company, 2011.

Hughes, Ted. Birthday Letters. London: Faber \& Faber, 1998.

Hutchison, Sharla. “The Eco-Poetics of Marianne Moore's 'The Sycamore'.” Interdisciplinary Studies in Literature and Environment 18:4 (2011): 763-778.

Kadlec, David. "Marianne Moore, Immigration, and Eugenics.” Modernism/Modernity 1:2 (1994):

21-49.

Kenner, Hugh. “Artemis and Harlequin.” National Review 19 (26 Dec. 1967): 1432-33.

Kramer, Margaret A. "Imaginary Gardens With Real Toads: Attachment to Others, Attachment to the Market." Psychotherapy 41:3 (Fall 2004): 208-216.

Kroiz, Lauren. Creative Composites: Modernism, Race and the Stieglitz Circle. Berkeley: University of California Press, 2012.

Lakritz, Andrew M. Modernism and the Other in Stevens, Frost and Moore. Gainesville: University Press of Florida, 1997

Leavell, Linda. Holding On Upside Down: The Life and Work of Marianne Moore. New York: Farrar, Straus and Giroux, 2013.

---. Marianne Moore and the Visual Arts: Prismatic Color. Baton Rouge: Louisiana State University, 1995.

---. "Marianne Moore, the James Family, and the Politics of Celibacy." Twentieth Century Literature 49:2 (Summer 2003): 219-245.

Lourdeaux, Stanley. "Toads in Gardens for Marianne Moore and William Carlos Williams." Modern Philology 80:2 (Nov. 1982): 166-167.

Miller, Cristanne. "Marianne Moore's Black Maternal Hero: A Study in Categorization," American Literary History 1:4 (Winter 1989): 86-815.

---. Marianne Moore: Questions of Authority. Cambridge: Harvard University Press, 1995.

---. “The Politics of Marianne Moore's Poetry of Ireland." Irish Journal of American Studies 11/12 (2002/2003): 1-17.

Moore, Marianne. Adversity and Grace: Marianne Moore, 1936-1941. Ed. Heather Cass White. Victoria: ELS Editions, 2012. 
---. Becoming Marianne Moore: The Early Poems, 1907-1924. Ed. Robin Schulze. Berkeley: The University of California Press, 2002.

---. Complete Poems. 1967. New York: Penguin, 1994.

---. The Complete Prose of Marianne Moore. Ed. Patricia C. Willis. New York: Viking, 1986.

---. New Collected Poems. Ed. Heather Cass White. New York: Farrar, Straus and Giroux, 2017.

Nancy, Jean-Luc. “Eloge de la mêlée.” Transeuropéennes 1 (Jan. 1993): 8-18.

Olson, Kirby. “Marianne Moore's ‘The Camperdown Elm' and the Revival of Brooklyn's Prospect Park." Journal of Ecocriticism 3:2 (July 2011): 16-27.

Plath, Sylvia. Letters Home by Sylvia Plath. Ed. Aurelia Schober Plath. New York: Harper \& Row, 1975.

Price, P. David. "Real Toads in Imaginary Gardens: Aspelin vs. Lévi-Strauss on Nambiquara Nomadism." Bijdragen Tot De Taal-, Land- En Volkenkunde 134:1 (1978): 149-161.

Rotella, Guy. Reading and Writing Nature: The Poetry of Robert Frost, Wallace Stevens, Marianne Moore, and Elizabeth Bishop. Boston: Northeastern University Press, 1991.

Schulze, Robin. “'Injudicious Gardening': Marianne Moore, Gender, and the Hazards of Domestication." In Critics and Poets on Marianne Moore: "A Right Good Salvo of Barks." Eds. Linda Leavell, et al. Lewisburg: Bucknell University Press, 2005. 74-89.

---. "Marianne Moore's 'Imperious Ox, Imperial Dish' and the Poetry of the Natural World." Twentieth Century Literature 44:1 (1998a): 1-33.

---. “Textual Darwinism: Marianne Moore, the Text of Evolution, and the Evolving Text.” Text 11 (1998b): 270-305.

Slatin, John M. “'Advancing Backward in a Circle': Marianne Moore as (Natural) Historian.” Twentieth Century Literature 30:2/3, Marianne Moore Issue (Summer-Autumn, 1984): 273-326.

---. The Savage's Romance: The Poetry of Marianne Moore. University Park: Pennsylvania State University Press, 1986.

---. “'Something Inescapably Typical': Questions about Gender in the Late Work of Williams and Moore." William Carlos Williams Review 14:1 (Spring 1988): 86-103.

Sprague, Rosemary. Imaginary Gardens: A Study of Five American Poets. Philadelphia: Chilton Book Co., 1969.

Stevenson, Robert Louis. A Child's Garden of Verses. London: Longmans, Green, 1911.

Swann, Charles. "Gardens and Toads or, Milton-Another Fly in Marianne Moore's Amber?" Notes and Queries 41:3 (Sept. 1994): 376-377.

Tomlinson, Charles (ed.). Marianne Moore: A Collection of Critical Essays. Englewood Cliffs: Prentice Hall, 1969.

Westover, Jeffrey W. The Colonial Moment: Discoveries and Settlements in Modern American Poetry. Dekalb: Northern Illinois University Press, 2004.

Williams, William Carlos. The Autobiography of William Carlos Williams. New York: New Directions, 1967.

Willis, Patricia C. (ed.). Marianne Moore Newsletter 1 (1977).

--- (ed.). Marianne Moore: Woman and Poet. Orono, ME, National Poetry Foundation, 1990. 
Yeager, D. M. "Real Toads in Imaginary Gardens: Impossibility and Perfection in Christian Ethics." The Annual of the Society of Christian Ethics 19 (1999): 145-165.

\section{NOTES}

1. For an overview of the numerous editorial changes undergone by "Poetry," see for instance Bonnie Honigsblum, "Marianne Moore's Revisions of 'Poetry," and Robin Schulze, "Textual Darwinism: Marianne Moore, the Text of Evolution, and the Evolving Text."

2. The quoted text is from Marianne Moore's Observations ( $1^{\text {st }}$ ed., 1924), reproduced in Heather Cass White's New Collected Poems of Marianne Moore (2017), which will be my reference edition in this article, unless otherwise specified. As she explains in her illuminating critical apparatus, Heather Cass White aims to propose an alternative version of Moore's corpus, rendering newly accessible texts that the poet had "cut and trimmed in radical and merciless ways" (Hecht 208) in her final Complete Poems (1967). Against the "final intentions" principle that dominates editorial theory, Heather Cass White argues that her work "exists in the service of the Moore her peers witnessed, and as a counter-testimony to the Moore she herself invented to take her place" (344). Whenever useful, my analysis will also rely on Moore's Complete Poems or on facsimile editions of her early publications by Robin Schulze and Heather Cass White.

3. If the speaker's imaginary interlocutor remains unnamed, critics have identified as a possible source a quotation from The Note-books of Samuel Butler (1912) in which the British author gives the following reply to a young poetry amateur in Italy, asking if he also thought Longfellow was "a pretty poet": "Oh yes, but I don't greatly like poetry myself. [...] You see, poetry resembles metaphysics, one does not mind one's own, but one does not like anyone else's." (Butler, quoted in Willis 1977, 10)

4. In the second and third stanzas of "Poetry," Moore lists several animal and human specimens in action, it seems as so many instances of "[important] things" or counterexamples to "derivative" interpretations, but the grammatical construction and the visual scheme of the stanza renders the enumeration ambiguous.

5. Moore's endnote to the poem reads: "Diary of Tolstoy; Dutton, p. 84: 'Where the boundary between prose and poetry lies, I shall never be able to understand. The question is raised in manuals of style, yet the answer to it lies beyond me. Poetry is verse; prose is not verse. Or else poetry is everything with the exception of business documents and school books." (Moore 297)

6. See for example David Booth “'Imaginary Gardens with Real Toads': Reading and Drama in Education"; David P. Price, "Real Toads in Imaginary Gardens: Aspelin vs. Lévi-Strauss on Nambiquara Nomadism"; D. M. Yeager, "Real Toads in Imaginary Gardens: Impossibility and Perfection in Christian Ethics"; or Margaret A. Kramer, "Imaginary Gardens With Real Toads: Attachment to Others, Attachment to the Market."

7. Elizabeth Gregory notes that out of the fifty-three poems assembled in Moore's Observations (1924), thirty-seven contained explicit borrowings (indicated by quotations marks or in the endnotes), against sixteen out of the eighteen pieces composing Tell Me, Tell Me (1966), the last collection she published before her Complete Poems (1967). For a more detailed computing of Moore's quotations, see Gregory 1996, 186.

8. For the longer version of "Poetry" reproduced in the endnotes, see Moore 1994, 266-267. For the first two versions of the poem in which the phrase appears without quotation marks, see Moore 2002, 72-73, 205.

9. See Moore 297.

10. See Stanley Lourdeaux's notes in "Toads in Gardens for Marianne Moore and William Carlos Williams." 
11. See Charles Swann, "Gardens and Toads or, Milton-Another Fly in Marianne Moore's Amber?"

12. Those of Moore's poems that more exclusively focus on the human body (with a predilection for dancers and sportsmen) do evince a tension between the fragmentation and freezing effects of her writing, and the dynamism she prized in natural movements. But the surgical trope is rarely evoked as such, apart from the modernist blazon featured in "Those Various Scalpels."

13. Surveying the Bryn Mawr program for the academic year 1907-1908, David Ross Anderson mentions that Moore took "all courses required of majors in the subject, including General Biology, Plants, Vertebrates, Embryology, Animal Physiology, Zoology, Comparative Anatomy, Theoretical Issues (which included Darwinian theory), all of which required lab work." (Anderson 33).

14. In a letter to T.S. Eliot (July 2, 1934), Moore praised him for his "congregation of animiles at the front" of her Selected Poems, which he edited in 1935 (quoted in Holley 78-79).

15. An alternative title is "The Monkey Puzzle," found most notably in the Complete Poems.

16. Among various references, see Bonnie Costello, Marianne Moore: Imaginary Possessions and Shifting Ground: Reinventing Landscape in Modern American Poetry; Guy Rotella, Reading and Writing Nature: The Poetry of Robert Frost, Wallace Stevens, Marianne Moore, and Elizabeth Bishop; or more recently Robin Schulze, The Degenerate Muse: American Nature, Modernist Poetry and the Problem of Cultural Hygiene or Sharla Hutchinson, "The Eco-Poetics of Marianne Moore's 'The Sycamore."

17. See in particular Cristanne Miller, Questions of Authority, 93-127; Robin Schulze, “Injudicious Gardening": Marianne Moore, Gender, and the Hazards of Domestication" and The Degenerate Muse: American Nature, Modernist Poetry and the Problem of Cultural Hygiene, 189-192; and Linda Leavell, Marianne Moore and the Visual Arts: Prismatic Colour, 126-127.

18. See for example David Kaldec, "Marianne Moore, Immigration, and Eugenics"; Cristanne Miller, "Marianne Moore's Black Maternal Hero: A Study in Categorization," and "The Politics of Marianne Moore's Poetry of Ireland."

19. "Virginia Britannia" is the main focus of John Slatin, "Advancing Backward in a Circle': Marianne Moore as (Natural) Historian" and Jeffrey Westover in The Colonial Moment: Discoveries and Settlements in Modern American Poetry.

20. The original context of publication for each poem is also indicative of the evolution: while "Injudicious Gardening" was first published as "To Browning" in a 1915 issue of an avant-garde magazine, The Egoist (Aug. 2, 1915), "In the Public Garden" was more widely accessible as it initially appeared as "A Festival," in The Boston Globe (June 15, 1958).

21. In a review of her Selected Poems, John Ashbery is "tempted simply to call her our greatest modern poet" while also comparing her moralizing persona to La Fontaine, Joubert or Poor Richard. Louise Bogan sees her as an "American Timeless" but also a strange blend of baroque profusion and protestant austerity (see Gregory 2003, 144, 223).

22. Before R. P. Blackmur wondered about Moore's "special chastity aside from the flesh" (quoted in Tomlinson 85) Hart Crane had privately called her a "hysterical virgin" and "Rt. Rev. Miss Mountjoy" (Hughes 2011, 54-55). Moore's most famous portrait as a modernist saint is found in William Carlos Williams' Autobiography (Williams 146). The poet also appears as a cerebral rather than mystical Dickinson in a comment by Pearl Anderson (quoted in Gregory 2003, 46).

23. See in particular Elizabeth Gregory's discussions of Moore's late poetry in "Stamps, Money, Pop Culture and Marianne Moore," and "'Still Leafing': Celebrity, Confession, Marianne Moore's 'The Camperdown Elm' and the Scandal of Age." Gregory's contention-which I share-is that Moore's writings embraced new complexity rather than being marked by a thematic and formal decline. Cristanne Miller also provides an enlightening discussion of the paradoxes of Moore's public persona in a chapter dedicated to "Quotation, Community and Correspondences" (Miller 1995, 167-203). For an example of the less appreciative assessments of Moore's late phase, see 
John Slatin, “'Something Inescapably Typical': Questions about Gender in the Late Work of Williams and Moore".

24. Even apparent exceptions to this rule reveal themselves to bear on unique individuals, as in "Roses Only" or "Pigeons" for example.

25. For a detailed account of the poem and its context, see Kirby Olson, "Marianne Moore's 'The Camperdown Elm' and the Revival of Brooklyn's Prospect Park."

26. Moore's first of two notes reads: "the Chili pine: araucaria imbricata. Arauco-a territory in Araucania which is in the southern part of Chili: imbricatus-crooked like a gutter, or roof-tile; or laid one under another like tiles" (Moore 297).

27. In the endnotes, "a certain proportion in the skeleton" is attributed to Lafcadio Hearn (Moore 297).

\section{ABSTRACTS}

Moore is certainly best known for her oddly meticulous plant and animal descriptions, which the phrase "imaginary gardens with real toads in them" has sometimes come to synthesize. This article reexamines some of these peculiar specimens in light of the tensions they engage between exceptionality and representativeness. Relying on processes of selection and inclusion, the poetics of grafting at work in her botanical pieces seem to entail the assimilation of heterogenous elements-whether vegetable or literary scions-into one organism and single habitat, which could thereby be made to represent the space for a democracy of species and voices. But while Moore's integration of diversity does evince a growing participation in the arena of public discourse, her idiosyncratic writing also resists synthesis and keeps cultivating exception. More than the specimens of a common species, her hybrid creatures are staged as composite singular cases, whose poetic and political mode of existence is that of the "melee" rather than the "melange" (Nancy).

De Marianne Moore, on connaît sans doute le mieux les descriptions à la fois étranges et minutieuses de plantes ou d'animaux, que la formule «imaginary gardens with real toads in them » en est parfois venue à résumer. Cet article réexamine certains de ces curieux spécimens à l'aune des tensions qu'ils engagent entre exceptionnalité et représentativité. À travers les processus de sélection et d'inclusion qui la fondent, la poétique de la greffe, que mettent particulièrement en jeu ses textes botaniques, semble présupposer l'assimilation d'éléments hétérogènes-greffons végétaux ou littéraires-en un même organisme et un unique habitat, qui en viendrait à représenter l'espace d'une démocratie des voix et des espèces. Si, en intégrant le divers, l'œuvre de Moore paraît elle-même s'incorporer de plus en plus dans l'arène publique, elle n'en continue pourtant pas moins de cultiver l'exception. Plus que les spécimens d'une espèce commune, ses créatures hybrides s'offrent comme autant de singularités composites, dont la "mêlée" plus que le "mélange" (Nancy) devient le mode d'existence poétique autant que politique. 
INDEX

Keywords: Marianne Moore (1887-1972), exception, poetry, poetics, grafting, quotation, politics, inclusion, representativeness, hybridity, singleness, singularity

Mots-clés: Marianne Moore (1887-1972), exception, poésie, poétique, greffe, citation, politique, inclusion, représentativité, hybridité, célibat, singularité.

\section{AUTHOR}

\section{AURORE CLAVIER}

Maîtresse de conférences

Université de Lille

aurore.clavier@univ-lille.fr 